\title{
AIDS: an old disease from Africa?
}

\author{
KEVIN M DE COCK
}

Many possible causes for the acquired immunodeficiency syndrome (AIDS) have been proposed since its first recognition in American homosexual men. ${ }^{12}$ Investigation has centred on the search for an infectious agent (or agents), most probably viral, ${ }^{3}$ and suggested aetiologies have included hepatitis B virus or a hepatitis B virus associated particle, ${ }^{45}$ cytomegalovirus, ${ }^{6}$ African swine fever virus, ${ }^{7}$ and human $T$ cell leukaemia virus. ${ }^{8}$ Recently, major interest was aroused by the French discovery of lymphadenopathy associated virus, ${ }^{9}$ isolated from a case of the homosexual lymphadenopathy syndrome, and by the American recognition in patients with AIDS of retroviruses belonging to the group of human $T$ lymphotropic retroviruses collectively designated HTLV-III. ${ }^{10}$ Any suggested aetiology must explain the epidemiology and clinical manifestations of AIDS. Why homosexuals, drug users, and haemophiliacs? What is the link with Haiti? Why Kaposi's sarcoma ? Is this a new disease? Why has it appeared now, and where has it come from?

This report proposes that the infectious agent causing AIDS, whatever its nature, is endemic and unrecognised in parts of sub-Saharan Africa, from where it recently disseminated into external populations. No other explanation unifies the confusing observations on the syndrome. At very least, the common features of AIDS and the pattern of disease in equatorial Africa demand intensive research. Although the possibility that AIDS originated in Africa has been widely mentioned, this hypothesis has not previously been examined in detail.

\section{Is AIDS a new disease?}

Previous unrecognised infectious diseases often cause alarm, as witnessed by reactions to legionnaires' disease and the toxic shock syndrome. We have no evidence that any recently described infection is caused by a genuinely new agent.

In rural Africa diagnosis is often inexact. Fever is readily attributed to malaria without confirmation, ${ }^{11}$ and pneumonia is often assumed to be pneumococcal or tuberculous. Lack of facilities and the sheer volume of patients generally preclude more than basic investigation. Infections of all kinds are endemic and the major cause of death. ${ }^{12} 13$ In such a situation immunodeficiency would go unrecognised.

Useful analogies can be drawn between the sudden appearance of AIDS and the recent recognition of some African viral haemorrhagic fevers. Only three outbreaks of Marburg virus disease have been documented, the first in laboratory workers in Europe, ${ }^{14}$ the second in South Africa, ${ }^{15}$ and the third in Kenya. ${ }^{16}$ The index case each time was a white person. Seroepidemiological studies indicate that infection must be occurring all the time, ${ }^{17}$ but it is recognised only with access to highly advanced virological investigation, unavailable to rural Africans.

Ebola virus remained undetected until the magnitude of epidemics

University of Southern California Liver Unit, Rancho Los Amigos Hospital, Downey, California 90242, USA

KEVIN M DE COCK, MRCP, DTM\&H, clinical fellow in southern Sudan ${ }^{18}$ and northern Zaire ${ }^{19}$ attracted the world's attention. Sexual promiscuity is thought to have been important in the initial spread of this disease outside hospital (D H Smith, personal communication). Here, then, was a "new" African virus causing epidemics with high mortality, capable of being spread sexually.

The final analogy is with Lassa fever, first described in a missionary nurse in north eastern Nigeria. ${ }^{20}$ Despite initial alarm surrounding this disease, ${ }^{21}$ subclinical infection is now realised to be common. ${ }^{22}$ Just as deaths from Lassa fever are atypical, so full blown immune deficiency may be unrepresentative of infection with the AIDS agent. The AIDS agent may exist in stable equilibrium with its rural African environment, but in a new population its expression may be altered by various factors including different innate susceptibility. Measles exemplifies this, being a generally mild infection that is nevertheless capable of decimating populations not previously exposed to it.

Like the viral haemorrhagic fevers, AIDS is an impressive disease that would not go unrecognised in the West. As the concept of genuinely new infectious organisms has no supporting evidence the AIDS agent has presumably existed undetected-in the same way as have these other infections in rural tropical Africa.

\section{AIDS, Kaposi's sarcoma, and African medicine}

Extensive use of drugs that suppress cellular immunity, in transplantation, oncology, and autoimmune disorders, has resulted in a few cases but not an epidemic of Kaposi's sarcoma. The tumour must have a specific aetiology, rather than just developing under conditions of impaired tumour surveillance. As Kaposi's sarcoma was a feature in about one third of reported cases of AIDS, ${ }^{3}$ it would seem mandatory to look for AIDS where Kaposi's sarcoma has its highest incidence in the world, equatorial Africa.

There are few published studies examining immunological function in African patients with Kaposi's sarcoma. Although classical African Kaposi's sarcoma is an indolent tumour, the neoplasm in patients with AIDS tends to be more malignant. ${ }^{23}$ An aggressive variety of Kaposi's sarcoma is seen in African children and young adults in whom lymph nodes and viscera are affected, and such patients, perhaps a tenth of all cases, have been shown to have impaired cell mediated immunity. ${ }^{24} \mathrm{~A}$ recent Zambian study showed that patients with classical Kaposi's sarcoma had decreased ratios of $T$ helper cells to $T$ suppressor cells, as do patients with AIDS, as well as various serological changes common in AIDS. ${ }^{25}$ The validity of patient and control matching in this study was questioned by other experienced workers. ${ }^{26}$ The relevance of African Kaposi's sarcoma to AIDS is an important question, and it is surprising that the whole issue of the African tumour and its immunology has not received more attention.

Kaposi's sarcoma is most common in eastern and western Zaire, Rwanda and Burundi, western Uganda, Tanzania, Malawi, and Kenya, in roughly that order. ${ }^{27}$ The great regional variation in prevalence ard the finding of time-space clustering in Uganda's West Nile District ${ }^{28}$ support an infectious aetiology. Cytomegalovirus antigen and specific DNA have been found in Kaposi's sarcoma tissue ${ }^{28}$ (and cytomegalovirus infection is ubiquitous in patients with AIDS), but a firm oncogenic role for the virus has not been proved. Immunosuppression by an AIDS agent may be required before the specific factor causing Kaposi's sarcoma can induce its effects. Other long term complications of tropical infections-for example, tropical splenomegaly syndrome and hepatocellular carcinoma-occur outside Africa, but Kaposi's sarcoma in high prevalence is geographically restricted to the above areas. This observation must be relevant. 
Other tumours complicating AIDS include Burkitt's lymphoma as well as Hodgkin's and non-Hodgkin's lymphoma. ${ }^{29}$ Burkitt's lymphoma has always been rare in non-tropical settings. Although endemic foci exist elsewhere, Burkitt's lymphoma is most common in areas constituting a band across Africa, the "lymphoma belt."30 $31 \mathrm{By}$ otherwise strange coincidence, the "lymphoma belt," $15^{\circ}$ north and south of the equator, encompasses the areas described above where Kaposi's sarcoma is endemic. There is strong evidence that the Epstein-Barr virus, a common infective agent in patients with AIDS, is causally relevant in African Burkitt's lymphoma, ${ }^{32}$ but the importance of modulating influences such as stable malaria ${ }^{33}$ or some other unidentified agent remains uncertain.

Lymphomas other than Burkitt's are also strikingly prevalent in the same geographical region. In Kenya lymphoma is the third most common solid tumour after carcinomas of the skin and cervix. ${ }^{34} \mathrm{~A}$ disproportionately high prevalence of lymphoma has also been documented in Uganda. ${ }^{35}$ The neoplastic complications of AIDS have much in common with patterns of cancer in equatorial Africa, and the similarities deserve further study.

Patients with AIDS have a high prevalence of enteric infections not typical in other Western immunosuppressed patients. Entamoeba, Giardia, Cryptosporidium, Ascaris, Trichuris, Salmonella, and Shigella are some of the pathogens documented in AIDS ${ }^{36}$ but unusual in other immunosuppressed patients. Presumably many of these infections in AIDS arise from exposure to faecal material in the context of sexual activity centred on the gastrointestinal tract. Such infections, common also with poor living conditions in rural Africa, may serve to enhance immune deficiency. To what extent Pneumocystis occurs in the tropics is not certain. Lung biopsy is usually required for diagnosis, and few hospitals can perform it.

\section{The Haitian connection}

The high prevalence of AIDS in Haitians, in many of whom homosexuality and drug abuse have not been obvious factors, has not been explained. Definite cases of AIDS have occurred in Haiti since 1979, and the opinion of experienced Haitian workers must be accepted that Kaposi's sarcoma was seen only once before 1979 in that country. ${ }^{36}$ As the tumour is most often diagnosed on inspection and biopsy specimens are readily taken, appreciable underdiagnosis is unlikely. The present outbreak of Kaposi's sarcoma and opportunistic infections in the United States began in $1978,{ }^{3}{ }^{37}$ although isolated cases may have occurred even earlier. AIDS in the United States would seem to antedate that in Haiti.

The ecology of Haiti resembles that of other Caribbean countries, and there is no reason why any endemic viral disease should localise itself to one island. If AIDS were traditionally endemic in Haiti one would have expected it also to occur in the neighbouring Dominican Republic, but this has apparently not been the case.

AIDS was probably introduced to Haiti by vacationing American homosexuals for whom the island was a fashionable resort in the late 1970 s. It is easy to see how in a poor country a young man, not necessarily primarily homosexual, might become intimately involved with an affluent group of foreigners. ${ }^{38}$ Once thus established AIDS could spread in a small population with relaxed attitudes towards heterosexual relations and a strong sense of community among members emigrating to the American mainland. Interestingly, Haitian born patients with AIDS are the only group in the United States in whom AIDS has become proportionately less prevalent compared with others at high risk. ${ }^{39}$

The incubation period of AIDS is thought to be one or more years. The first American cases are likely to have become infected in the early to mid-1970s, a time when tourism from the United States to Africa was developing as a result of heightened cultural interest. There now exists an increasing number of well documented cases of AIDS in black Africans, ${ }^{40-45}$ mainly Zaireans, in whom obvious risk factors were lacking. One case dates back to $1977,{ }^{43}$ a year before the first reported American cases. In addition, the case has been reported of a Danish surgeon who almost certainly died of AIDS in 1977, having first become ill in Zaire in $1976 .{ }^{46}$ In continental Europe heterosexual black Africans and their sexual partners now constitute an important risk group for AIDS. ${ }^{44} \mathrm{~A}$ detailed report from Belgium documented AIDS or its prodrome in 23 patients from central Africa who had no history of homosexuality, drug abuse, or blood transfusions. ${ }^{45}$ Half of these patients went to Belgium specifically for medical treatment, and the others had been living outside Africa for only a short time. A case report from England has also documented AIDS and Kaposi's sarcoma in a Ugandan woman without obvious risk factors. ${ }^{47}$ It must be concluded that these patients contracted the condition in Africa. The hypothesis that AIDS is an African disease best explains the ethnic and temporal descriptions of the syndrome.

\section{Homosexuals, heroin, haemophiliacs, hepatitis, and human $T$ lymphotropic retroviruses}

About four fifths of patients with AIDS have some serological marker of past or current infection with hepatitis $B$ virus, and this virus was earlier seriously proposed as the causative agent. ${ }^{45}$ Although the evidence is against hepatitis $B$ virus or an associated particle having a causative role, hepatitis $B$ virus provides an excellent epidemiological model of transmission. If hepatitis B virus were the cause full blown AIDS would have been recognised in areas of the world where infection with hepatitis B virus is endemic and advanced medical care is available, as in the Far East. Also, the hypothesis of hepatitis B virus as a causative agent does not explain why AIDS has surfaced at the present time while "serum hepatitis" was recognised long before its virology was understood. ${ }^{48}$

The elusive nature of the AIDS agent is no surprise to clinicians familiar with non-A, non-B hepatitis. Infection with hepatitis $B$ virus shows how a virus can spread through three apparently distinct groups -namely, homosexuals, haemophiliacs, and drug users. The commercial nature of blood donation in the United States ${ }^{49}$ and the greater interaction there than in Europe between the homosexual and drug using communities may in part explain why AIDS has been particularly a North American problem.

Infection with hepatitis B virus is endemic in patients with AIDS as well as in the condition's putative African source. In Kenya $12.2 \%$ of adults living in rural areas have been found to have hepatitis $B$ surface antigen in serum, while $80 \%$ show some marker of previous exposure to hepatitis B virus. ${ }^{50}$ It is not clear how hepatitis B virus infection maintains its high prevalence in Africa. Unlike in the Far East, vertical transmission is not thought to be a major factor. ${ }^{51}$ The mode of transmission of hepatitis B virus clearly differs in Africa from in Western patients with AIDS, and the same would be true for the AIDS agent itself.

Experience in hepatitis and venereology clinics suggests that fear of AIDS has affected homosexual behaviour. ${ }^{52}{ }^{53}$ This could result in future reduction of hepatitis B virus infection as well as of AIDS without the two being causally related.

Recently retroviruses have been favoured as the possible cause of AIDS. ${ }^{54}$ These agents were suggested because some retroviruses cause immune deficiency and tumours in animals and because antibodies to certain retroviruses have been commonly detected in patients with AIDS. In addition, some agents in the HTLV group specifically disturb $T$ cell function and are capable of being spread by intimate personal contact. The French discovery of lymphadenopathy associated virus ${ }^{8}$ and subsequent description in AIDS of immune deficiency associated virus, ${ }^{55}$ along with the American finding of HTLV-III agents in patients with AIDS, ${ }^{10}$ make retroviruses the leading contenders at present for a causal role.

Despite recent advances, ${ }^{910}$ 54-57 inadequate data exist as yet to incriminate retroviruses unquestionably as the cause of AIDS. It is still uncertain whether HTLV-III, lymphadenopathy associated virus, and immune deficiency associated virus are identical agents. Not all patients with AIDS who have been studied had detectable markers of these viral infections. Most importantly, association is not proof of cause, and these agents, like cytomegalovirus, might possibly turn out to be coincidental passengers in these multiply infected patients.

There is a need for international seroepidemiological studies of infection with HTLV-III and allied agents, including in African patients with AIDS and in areas in which Kaposi's sarcoma is endemic. Infection with HTLV-I is common in patients with AIDS but is also common in the Orient, where AIDS has not declared itself. Essential evidence for a causal role for HTLV-III will be the prospective showing of an increased relative risk of developing AIDS in people infected with this virus and, ultimately, reduction in the incidence of AIDS after prevention of HTLV-III infection. Finally, any causal agent must explain the epidemiology of AIDS and its sudden appearance in the West.

\section{Conclusions}

AIDS is almost certainly caused by an infectious agent independent and distinct from hepatitis $B$ virus but transmitted in similar fashion. Although attention is currently focused on a 
number of lymphotropic retroviruses as the aetiological agent, the origin, epidemiology, and clinical manifestations of the syndrome have not been explained. The concept of a new disease is untenable. The association with Haiti has caused confusion. AIDS in the United States antedated that in Haiti, and the disease was probably introduced into the Haitian population by American homosexuals. It is suggested that the first Americans with AIDS acquired the condition in the early 1970s in Africa. AIDS is being increasingly recognised in black Africans, and the early African cases preceded the first documented American cases by several years.

The hypothesis that AIDS originated in rural equatorial Africa best explains the sudden emergence and clinical features of the syndrome. The clinical spectrum of AIDS, with Kaposi's sarcoma, Burkitt's lymphoma, other lymphomas, enteric infections, and other parasitic diseases, is strikingly reminiscent of the pattern of disease in sub-Saharan Africa. Inadequate attention has been paid to the geographical pathology of the diverse manifestations of this "new" syndrome.

The arguments put forward are my own, but I thank various colleagues for discussion. I am grateful to Ruth Nao for secretarial help.

\section{References}

Anonymous. Pneumocystis pneumonia. Los Angeles Morbid Mortal Weekly Rep $1981 ; 30: 250-2$.

Anonymous. Kaposi's sarcoma and Pneumocystis pneumonia among homosexual men-New York City and California. MMWR 1981;30:305-8.

McDonald MI, Hamilton Jears later. $N$ Engl f Med $1983 ; 309: 609-11$. harbour the infective agent of AIDS. Lancet $1983 ;$ ii $: 882-4$.

Ravenholt RT. Role of hepatitis B virus in acquired immunodeficiency syndrome. Lancet 1983;ii:885-6.

Drew WL, Conant MA, Miner RC, et al. Cytomegalovirus and Kaposi's sarcoma in young homosexual men. Lancet 1982 ;ii:125-7.

Teas J. Could AIDS agent be a new variant of African swine fever virus ? Lancet 1983;i:923.

Gallo RC, Sarin PS, Gelmann EP, et al. Isolation of human T cell leukemia virus in patients with AIDS. Science 1983;220:865-7.

等re-Sinoussi F, Chermann JC, Rey F, et al. Isolation of a T-lymphotropic retrovirus from a patient at risk

10 Gallo RC. Salahuddin SZ Popovic M, et al. Frequent detection and isolation of cytopathic retroviruses (HTLV-III) from patients with AIDS and at risk for cytopathic retroviruses (HTLV. Science 1984;224:500-2.

' Roberts JMD. Malaria. In: Vogel LC, Muller AS, Odingo RS, Onyango Z, de Geus A, eds. Health and disease in Kenya. Nairobi: East African Literature Bureau, 1974:305-18.

${ }^{12} \mathrm{King} \mathrm{MH}$. Medicine in an unjust world. In: Weatherall DJ, Ledingham JGG, Warrell DA, eds. Oxford textbook of medicine. Oxford: Oxford University Press,

1983:3.3-11.
${ }^{13}$ Bonte J. Patterns of mortality and morbidity. In: Vogel LC, Muller AS, Odingo RS, Onyango Z, de Geus A, eds. Health and disease in Kenya. Nairobi, East African Literature Bureau, 1974:75-90.

it Martini GA, Siegart R, eds. Marburg virus disease. Berlin: Springer Verlag, 1971. Gear JSS, Cassel GA, Gear AJ, et al. Outbreak of Marburg virus disease in Johannesburg. Br Med 7 1975; iv:489-93. $1982 ; \mathrm{i}: 816-20$.

17 Johnson BK, Ocheng D, Gichogo A, et al. Antibodies against haemorrhagic fever

Johnson BK, Ocheng D, Gichogo A, et al. Antibodies against haemorrhagic fever
viruses in Kenya populations. Trans Roy Soc Trop Med Hyg 1983;77:731-3.

s WHO International Study Team. Ebola haemorrhagic fever in Sudan, 1976. Bull WHO 1978;56:247-70.
'9 International Commission. Ebola haemorrhagic fever in Zaire, 1976. Bull WHO

$1978 ; 56: 271-93$.
20 Frame JD, Baldwin JM, Gocke DJ, Troup JM. Lassa fever, a new virus disease of man from west Africa. I. Clinical description and pathological findings, $A m \mathcal{F}$ Fuller JG. Fever! The hunt for a new

作 1974.

Monath TP. Lassa auci AS, Macher AM, Longo DL, et al. Acquired immunodeficiency syndrome epidemiologic, clinical, immunologic and therapeutic considerations. Ann

Intern Med 1984;100:92-106.
24 Taylor JF. Lymphocyte transformation in Kaposi's sarcoma. Lancet 1973;i:883-4. Downing RG, Eglin RP, Bayley AC. African Kaposi's sarcoma and AIDS. Lancet 1984;i:478-80.

${ }^{26}$ Greenwood BM, Whittle HC. Kaposi's sarcoma in Zambia. Lancet 1984 ; $1: 798$.

Hutt MSR. The epidemiology of Kaposi's sarcoma. Antibiot Chemother $1981 ; \mathbf{2 9}$ 3-8.

Giraldo G, Beth E, Kyalwazi K. Etiological implications on Kaposi's sarcoma. Antibiot Chemother $1981 ; 29: 12-29$

Good RA. Immunologic aberrations: the AIDS defect. In: Cahill KM, ed. The ATDS epidemic. New York: St. Martin's Press, 1983:41-62.

${ }^{31}$ Burkitt DP. Geographical distribution. In: Burkitt DP, Wright DH, eds. Burkitt's lymphoma. Edinburgh: Livingstone, 1970:186-97.

${ }^{32}$ Ziegler JL. Burkitt's lymphoma. $N$ Engl f Med $1981 ; 305: 735-45$.

3 Burkitt DP. Etiology of Burkitt's lymphoma-an alternative to a vectored virus. $\mathcal{f}$ Natl Cancer Inst 1969;42:19-28.

${ }^{34}$ Kungu A, Gatei DG. Kaposi's sarcoma in Kenya. Antibiot Chemother $1981 ; 29$ :

$38-55$.
${ }^{35}$ Davies JNP. Lymphomas and leukaemias in Uganda Africans. In: Roulet FC, ed. The lymphoreticular tumours in Africa. Basle: S Karger, 1963:67-79.

${ }^{36}$ Pape JW, Liautaud B, Thomas F, et al. Characteristics of the acquired immunodeficiency syndrome (AIDS) in Haiti. $N$ Engl f Med 1983;309:945-50

Anonymous. Update on Kaposi's sarcoma and opportunistic infections in Greviously healthy persons- Haiti and the stigma of AIDS. Lancet 1983 ;ii:515-6.

39 Areco RS. Haiti and the stigma of Amus. Lancet 1983 ;ii. States. $M M W R$. $1984 ; 33: 337-9$.
St

${ }^{\circ}$ Clumeck N, Mascart-Lemone F, De Maubeuge J, Brenez D, Marcelis L. Acquired immune deficiency syndrome in black Africans. Lancet $1983 ; \mathrm{i}: 642$.

${ }^{11}$ Offenstadt $G$, Pinta $P$, Hericord $P$, et al. Multiple opportunistic infection due to AIDS in a previously healthy black woman from Zaire. $N$ Englf $M e d 1983 ; 308$ : 775 .

12 Brunet JB, Bouvet E, Leibowitch J, et al. Acquired immunodeficiency syndrome in France. Lancet $1983 ; \mathrm{i}: 700-1$

Vandepitte J, Verwilghen R, Zachee P. AIDS and cryptococcosis (Zaire 1977). Lancet 1983;i :925-6.

Ebbesen P, Biggar RJ, Melbye M. AIDS in Europe. Br Med f 1983;287:1324-6. Clumeck $\mathrm{N}$, Sonnet J, Taelman $\mathrm{H}$, et al. Acquired immunodeficiency syndrome in African patients. $N$ Engl 7 Med $1984 ; 310: 492-7$.

Bygbierg I. AIDS in a Danish surgeon (Zaire 1976). Lancet 1983;i:925. dwards D, Harper PG, Pain AK, Welch J, Barbatis C, Mallinson C. Kaposi's sarcoma associated with AIDS in a woman from Uganda. Lancet 1984; :631-2. Zuckerman AJ, Howard CR. The history of viral hepatitis. In: Hepatitis viruses of

man. London: Academic Press, 1979:1-21.
t Rickard KA, Joshua DE, Campbell J, Wearne A, Hodgson J, Kronenberg H. Absence of AIDS in haemophiliacs in Australia treated from an entirely voluntary blood donor system. Lancet 1983; ii:50-1.

${ }^{50}$ De Cock KM. Splenomegaly and portal hypertension in Nairobi, Kenya: a study in geographical medicine. Bristol, University of Bristol, 1983. (MD thesis.)

${ }_{1}$ Whittle HC, Bradley AK, McLaughlan K, et al. Hepatitis B virus infection in two

Gambian villages. Lancet $1983 ; \mathrm{i}: 1203-6$.
52 Judson FN. Fear of AIDS and gonorrhoea rates in homosexual men. Lancet 1983;

Golubjatnikov R, Pfister J, Tillotson T. Homosexual promiscuity and the fear of AIDS. Lancet 1983 ;ii: 681 .

Popovic M, Sarngadharan MG, Read E, Gallo RC. Detection, isolation, and continuous production of cytopathic retroviruses (H

ss Vilmer E, Barre-Sinoussi F, Rouzioux C, et al. Isolation of a $T$ lymphotropic retrovirus from two siblings with haemophilia B, one with AIDS. Lancet 1984;

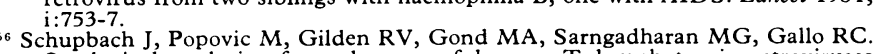
Serological analysis of a subgroup of human $T$ lymphotropic retroviruse (HTLV-III) associated with AIDS. Science $1984 ; 224: 503-5$.

Sarngadharan MG, Popovic M, Bruch L, Schupbach J, Gallo RC. Antibodies reactive with human T lymphotropic retroviruses (HTLV-III) in the serum of
patients with AIDS. Science 1984;224:506-8.

(Accepted 13 fuly 1984)

\section{Clinical curio: monoamine oxidase inhibitors and non-alcoholic beer}

Patients prescribed monoamine oxidase inhibitors are warned not to drink alcohol (product information; Smith, Kline, and French) because ethyl alcohol and monoamine oxidase inhibitors may potentiate one another's action ${ }^{1}$ and because certain alcoholic drinksnotably beers, some liqueurs, and fortified wine-contain substantial quantities of tyramine, which can lead to hypertensive crises in the presence of monoamine oxidase inhibitors. ${ }^{2}$ Patients are similarly advised not to eat foods with a high tyramine content. A patient who had been advised to drink, if at all, only small quantities of distilled spirits or dry white wine took a proprietary tablet containing tranylcypromine $10 \mathrm{mg}$ plus trifluoperazine $1 \mathrm{mg}$ for several years, varying the dose from one to three tablets daily. Only once did he suffer a "head," which was not typically vascular and related to drinking too much champagne at a wedding. A friend subsequently persuaded him to drink three bottles of a popular non-alcoholic beer, after which he suffered a severe typical vascular headache for the first time ever.

Gas-liquid chromatography showed that a sample of this non- alcoholic beer contained tyramine hydrochloride $10 \mu \mathrm{g} / \mathrm{ml}$, and $N$-methyltyramine $1.0 \mu \mathrm{g} / \mathrm{ml}$. A can of an English non-alcoholic lager showed lower but still appreciable concentrations of $0.7 \mu \mathrm{g} / \mathrm{ml}$ and $0.1 \mu \mathrm{g} / \mathrm{ml}$ respectively. The identities of these gas chromatographic peaks was confirmed mass spectrometrically. Normal beers may contain up to $10 \mu \mathrm{g} / \mathrm{ml}$ of tyramine.

Consumption of the newly introduced non-alcoholic beers and lagers is likely to increase. Doctors should be aware of their possible interaction with monoamine oxidase inhibitors. Patients receiving such drugs should be advised to abstain totally from certain specific types of alcoholic and non-alcoholic drink, especially beers, rather than from alcohol generally. - R DRAPER, assistant medical director, Dublin, M SANDLER, professor of chemical pathology, London, P L WALKER, biochemist, London.

1 Anonymous. Monoamine oxidase inhibitors. Br Med f 1968;ii:35-7.

2 Bethune HC, Burrell RH, Culpan RH, et al. Vascular crises associated with monoamine-oxidase inhibitors. Am $\mathcal{F}$ Psychiatry $1964 ; 121: 245-8$. 